\title{
Measured Performance Results: Low-Cost Solar Water Heating Systems in the San Luis Valley
}

Joel Swisher

January 1983

Prepared Under Task No. 1119.70

WPA No. 302

Solar Energy Research Institute

A Division of Midwest Research Institute

1617 Cole Boulevard

Golden, Colorado 80401

Prepared for the

U.S. Department of Energy

Contract No. EG-77-C-01-4042 


\author{
Printed in the United States of America \\ Available from: \\ National Technical Information Service \\ U.S. Department of Commerce \\ 5285 Port Royal Road \\ Springfield, VA 22161 \\ Price: \\ Microfiche $\$ 3.00$ \\ Printed Copy $\$ 4.50$
}

\title{
NOTICE
}

This report was prepared as an account of work sponsored by the United States Government. Neither the United States nor the United States Department of Energy, nor any of their employees, nor any of their contractors, subcontractors, or their employees, makes any warranty, express or implied, or assumes any legal liability or responsibility for the accuracy, completeness or usefulness of any information, apparatus, product or process disciosed, or represents that its use would not infringe privately owned rights. 


\section{PREFACE}

The San Luis Valley is a high desert valley in southern colorado. It is one of the poorest areas in the state and contains few natural resources. However, the San Luis Valley is endowed with abundant sunshine and with people committed to harnessing the sun's energy to provide heat and jobs. These people have initiated an explosion in solar energy use, resulting in perhaps the highest per capita concentration of solar installations in the country. The majority of these installations are low-cost, site-built retrofit systems that employ locally available materials and labor. Many were built under government grants and in community workshops, and others were built by private individuals.

Nearly 1000 solar devices have been installed in the San Luis Valley, showing great promise for fuel savings and local economic self-sufficiency. However, measured performance results on low-cost systems are scarce, and this type of information is necessary as more communities implement low-cost solar technology. As part of a program to measure the performance of innovative active solar heaters, SERI supplied equipment and methodology to monitor seven lowcost solar water heating systems during 1981 in the towns of Alamosa and San Luis. This report presents the results of this monitoring.

I wish to thank the following individuals for their contributions to this effort: Don Frey for technical guidance; Jimmie Boswell of SERI for electronics maintenance; and Mark Randall of the San Luis Valley Solar Energy Association, Andy Zaugg of Hot Stuff, and Arnie Valdez of People's Alternative Energy Services for installation and operation of the data acquisition equipment. I thank also the seven families who allowed us to monitor their solar water heaters.

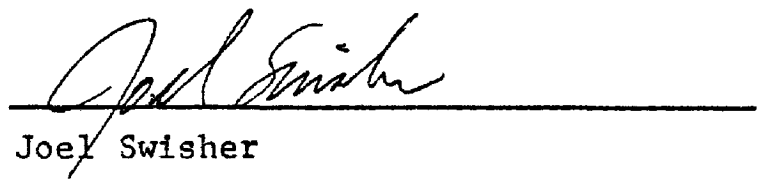

Approved for

SOLAR ENERGY RESEARCH INSTITUTE

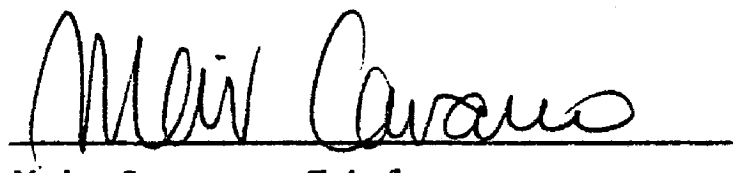

Meir Carasso, Chief

Building Systems Research Branch

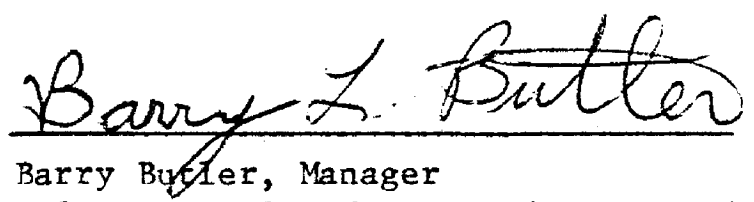

Solar Thermal and Materials Research Division 
SUMMARY

\section{OBJECTIVE}

To measure the thermal performance of a variety of low-cost solar water heating systems that are representative of the designs and components used in the San Luis Valley of southern Colorado.

\section{DISCUSSION}

SERI monitored seven low-cost solar water heating systems in the San Luis Valley during the summer and fall of 1981. SERI supplied the data acquisition equipment, performance evaluation methodology, and data reduction software. Technicians from the San Luis Valley Solar Energy Association installed, programmed, and operated the data acquisition systems. Measurements included solar radiation, outdoor temperature, collector inlet and outlet temperatures, domestic water temperatures, collector fluid and domestic water flow rates, and auxiliary water-heater energy use. From these quantities, the energy flows in each system were calculated, including collected solar energy, net solar and auxiliary heating, and gross auxiliary energy use. Collector and system efficiencies, coefficients of performance, and solar fractions were also calculated. The monitored systems represented a variety of low-cost solar water heating system designs and components. Five systems had sitebuilt collectors, and four included low-cost, tank-in-jacket heat exchanger/ storage tank components. Two of the systems were afr-to-water systems. The five Ifquid-based systems included a drain-down design, a propylene glycolcharged thermosiphon system, and three pumped-glycol systems.

\section{CONCLUSIONS}

- The pumped-liquid systems performed better than the thermosiphon and airto-water systems.

- The site-built, liquid-based collectors performed as well as the cormercial collectors.

- The thermosiphon system performed at low efficiency because of low collector flow rates.

- Air leakage in the air-to-water systems decreased collector performance and promoted thermosiphon heat losses.

- The measured efficiency of each system depended on the hot water demand.

- Future work should include further detailed testing of low-cost, freezeproof thermosiphon systems. 


\section{TABLE OF CONTENTS}

Page

$1.0 \quad$ Introduction........................................... 1

2.0 The Monitoring System............................. 3

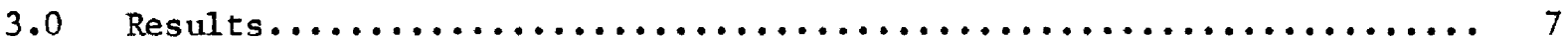

3.1 System 1: Alamosa Site-Built water Heating System......... 7

3.2 System 2: San Luis Site-Built Water Heating System......... 7

3.3 Systen 3: San Luis Site-Built Thermosiphon System.......... 10

3.4 System 4: San Luis Air-to-Water System................. 11

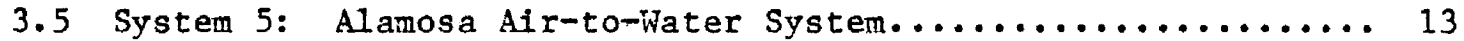

3.6 System 6: Alamosa Commercial Water Heating System.......... 13

3.7 System 7: San Luis Commercial Water Heating System......... 14

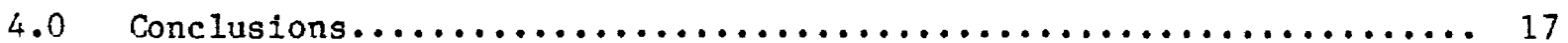

4.1 System Performance............................ 17

4.2 Collector Performance............................ 17

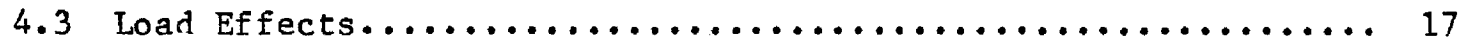

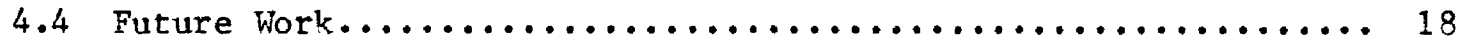

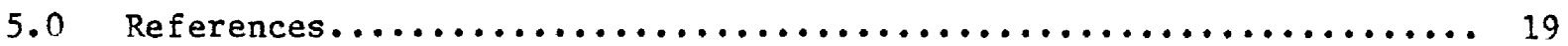

Appendix A: Detailed System Drawings....................... 21

Appendix B: Uncertainty Analysis.......................... 31

Appendix c: Horizontal Insolation Measurements................ 35 


\section{LIST OF FIGURES}

Page

3-1 Operational Characterist1cs of the Alamosa Site-Built Water Heater (Site 1) ................................... 10

3-2 Operational Characteristics of the San Luis Thermosiphon

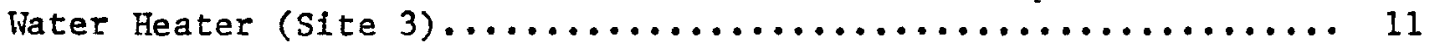

3-3 Operational Characteristics of the San Luis Air-to-Water System

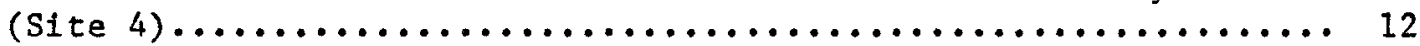

3-4 Operational Characteristics of the Alamosa Air-to-Water System

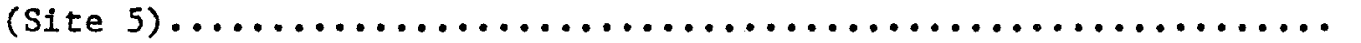

\section{LIST OF TABLES}

Page

2-1 Continuous Measurement Sensors...........................

$2-2$ Data Reduction Functions.............................

3-1 System Characteristics.............................

$3-2 \quad$ Performance summary.................................... 


\section{SECTION 1.0}

\section{INTRODUCTION}

This report summarizes the measured performance of seven low-cost solar water heating systems in the San Luis valley of southern Colorado. The systems were monitored during the summer and fall of 1981. Microprocessor-based data acquisition systems were supplied by the Solar Energy Research Institute (SERI) and installed and operated by technicians from the San Luis Valley Solar Energy Association (SLV/SEA) under contract to SERI. SERI also supplied the performance evaluation methodology and the data reduction software.

The objective of this monitoring was to investigate the thermal performance and fuel savings of low-cost solar water heaters, particularly site-built systems. The San Luis Valley contains a large assortment of such systems, as we11 as skilled individuals to assist with the monitoring program. This presented an opportunity to test the performance of several low-cost systems and to determine some of the associated benefits and problems.

A variety of low-cost solar water heating system designs and components were monftored. Five systems have site-built collectors, and two have commercial collectors. Four of the systems include low-cost, tank-in-jacket heat exchanger/storage tank components. Two of the systems are air-to-water systems. The five liquid systems include a drain-down design, a propylene glycol-charged thermosiphon system, and three pumped-glycol systems. The systems were installed by varying degrees of professional labor, resulting in a wide range of construction quality. 
SEPI 
SECTION 2.0

\section{THE MONITORING SYSTEM}

Each water heating system was monitored using a microprocessor-based data acquisition system (DAS) that was developed for the SERI Residential Class B Passive Solar Performance Monitoring Program [1]. The DAS was adapted to the water heating application by including fluid flow rate and temperature sensors in the hardware package and by reprogramming the data reduction software. Each system had a slightly different combination of sensors and software.

The DAS processed 14 data channels every 15 seconds and stored hourly channel averages on cassette tape. The sensors, described in Table 2-1, provided the measurements necessary to calculate a basic energy balance for each system. Storage tank temperature profiles and other specific component parameters were not measured.

In addition to collecting and storing raw data measurements, the DAS performed real-time data reduction, converting the raw channel data into system performance functions. The DAS printed daily summarles of the data reduction functions. The functions, listed in Table 2-2, included daily performance factors, which accumulated over a 24-hour period and were zeroed after each daily printout, and monthly performance factors, which accumulated over an entire month and were updated in the daily printouts and zeroed at the end of each month.

The basic energy flows in the system were calculated using a Btu-meter calculation, integrating the product of flow rate, specific heat, and temperature difference. The 15-second sampling period provided sufficient resolution to accurately integrate this type of function, which included the net solar and auxiliary heating and the gross solar energy collected by pumped-liquid systems. For air-to-water systems, the air flow rate was measured once, using hot-wire anemometry, and assumed constant whenever the collector fan operated. Collector flow was not measured for the thermosiphon system because a flowneter in the fluid path might have interfered with the flow. However, the flow rate could be approximated from the energy and temperature measurements.

For electric water heaters, the gross energy input to the auxiliary water heater was determined from measurements of the electric current drawn and the AC supply voltage. For fuel-fired water heaters, the on-time of the burner was monitored, and the fuel flow rate was measured once and assumed constant. 
Table 2-1. Continuous Measurement Sensors

\begin{tabular}{|c|c|c|c|}
\hline Description & Symbol & $\begin{array}{l}\text { Measurement } \\
\text { Units }\end{array}$ & Sensor \\
\hline Horizontal radiation & $I_{h}$ & $\mathrm{Btu} / \mathrm{h} \mathrm{ft}^{2}$ & LI-COR pyranometer \\
\hline Incident radiation & $I_{\text {In }}$ & $\mathrm{Btu} / \mathrm{h} \mathrm{ft}^{2}$ & LI-COR pyranometer \\
\hline Outside air temperature & $\mathrm{T}_{0}$ & $o_{F}$ & $\begin{array}{l}\text { AD590 integrated- } \\
\text { circuit temperature } \\
\text { sensor }\end{array}$ \\
\hline Collector inlet temperature & $T_{c o}$ & $o_{F}$ & AD590 \\
\hline Collector outlet temperature & $\mathrm{T}_{c i}$ & ${ }^{\circ} \mathrm{F}$ & AD590 \\
\hline Cold water supply temperature & $T_{1}$ & $o_{F}$ & $A D 590$ \\
\hline Water preheat temperature & $\mathrm{T}_{2}$ & $o_{F}$ & $\operatorname{AD} 590$ \\
\hline Hot water output temperature & $\mathrm{T}_{3}$ & $o_{F}$ & AD590 \\
\hline Collector flow & $\mathrm{F}_{\mathrm{c}}$ & gal & $\begin{array}{l}\text { Kent positive- } \\
\text { displacement } \\
\text { flowmeter } \\
\text { (pulse-initiating) }\end{array}$ \\
\hline Domestic water flow & $\mathrm{F}_{\mathrm{w}}$ & gal & Kent flowneter \\
\hline AC supply voltage & $\mathrm{v}$ & $\mathrm{v}$ & voltage transformer \\
\hline Collector pump/fan current & $\mathrm{EC}_{\mathrm{cp}}$ & A & $\begin{array}{l}\text { AMPROBE current } \\
\text { transducer }\end{array}$ \\
\hline $\begin{array}{l}\text { Water heater current } \\
\text { or burner on-tine }\end{array}$ & $\underset{\text { or }}{E C_{W}}$ & or $\mathrm{h}$ & $\begin{array}{l}\text { AMPROBE } \\
\text { or thermal switch }\end{array}$ \\
\hline Collector pump/fan on-time & $t_{c p}$ & h & relay \\
\hline
\end{tabular}


Table 2-2. Data Reduction Functions

\begin{tabular}{|c|c|c|c|}
\hline Description & Symbo1 & $\begin{array}{c}\text { Measurement } \\
\text { Units }\end{array}$ & Definition ${ }^{a}$ \\
\hline Gross solar energy collected & $Q_{g s}$ & Btu & $C_{p} \int F_{c}\left(T_{c o}-T_{c i}\right)$ \\
\hline Net solar heating & $Q_{n s}$ & Btu & $8.33 \int \mathrm{F}_{\mathrm{w}}\left(\mathrm{T}_{2}-\mathrm{T}_{1}\right)$ \\
\hline Net auxillary heating & $Q_{\text {na }}$ & Btu & $8.33 \int \mathrm{F}_{w}\left(T_{3}-T_{2}\right)$ \\
\hline Gross auxiliary energy use & $Q_{g a}$ & Btu & $\begin{array}{l}\mathrm{q}_{\mathrm{w}} \int \mathrm{t}_{\mathrm{w}}(\text { fuel }) ; \\
3.413 \int \mathrm{EC} \mathrm{C}_{\mathrm{w}} \mathrm{dt} \text { (elec.) }\end{array}$ \\
\hline Solar system heat loss & $Q_{s 1}$ & Btu & $Q_{g s}-Q_{n s}$ \\
\hline Collector pump/fan energy & $E_{c p}$ & Btu & $3.413 \mathrm{pf} \int \mathrm{EC} \mathrm{cp}_{\mathrm{p}} \mathrm{V} \mathrm{dt}$ \\
\hline Hot water use & $\mathrm{M}_{\mathrm{w}}$ & gal & $\int F_{W}$ \\
\hline Net water heating load & $\mathrm{Q}_{\mathrm{w}}$ & Btu & $Q_{n a}+Q_{n s}$ \\
\hline Average outdoor temperature & $\mathrm{T}_{0}$ & $o_{F}$ & $(1 / t) \int T_{0} d t$ \\
\hline Average cold water temperature & $\mathrm{T}_{1}$ & ${ }^{o} \mathrm{~F}$ & $\left(1 / M_{W}\right) \int F_{W} T_{1}$ \\
\hline Average preheat temperature & $\mathrm{T}_{2}$ & ${ }^{\circ} F$ & $\left(1 / \mathrm{M}_{\mathrm{w}}\right) \int \mathrm{F}_{\mathrm{w}} \mathrm{T}_{2}$ \\
\hline Average hot water temperature & $\mathrm{T}_{3}$ & ${ }^{o} \mathrm{~F}$ & $\left(1 / M_{W}\right) \int F_{W} T_{3}$ \\
\hline Horizontal radiation & $I_{h}$ & $\mathrm{Btu} / \mathrm{ft}^{2}$ & $\int I_{h} d t$ \\
\hline Incident radiation & $I_{1 n}$ & $\mathrm{Btu} / \mathrm{ft} \mathrm{t}^{2}$ & $\int I_{1 n} d t$ \\
\hline Average AC line voltage & $\mathrm{v}$ & volt & $(I / t) \int V d t$ \\
\hline Collector efficiency & $n_{\operatorname{col}}$ & -- & $Q_{g s} /\left(A_{c} I_{i n}\right)$ \\
\hline Net solar efficiency & $n_{\text {sol }}$ & -- & $Q_{n s} /\left(A_{c} I_{i n}\right)$ \\
\hline Auxiliary efficiency & $\eta_{\text {aux }}$ & - & $\mathrm{Q}_{\mathrm{na}} / \mathrm{Q}_{\mathrm{ga}}$ \\
\hline Solar fraction & $\mathrm{F}_{\text {sol }}$ & -- & $Q_{n s} /\left(Q_{n s}+Q_{n a}\right)$ \\
\hline Net coefficient of performance & $\mathrm{COP}_{\text {net }}$ & -- & $\mathrm{Q}_{\mathrm{ns}} / \mathrm{E}_{\mathrm{cp}}$ \\
\hline Collector pump cycles & $n_{c y c}$ & -- & -- \\
\hline \multicolumn{4}{|c|}{$\begin{aligned} A_{c} & =\text { collector area }\left(\mathrm{ft}^{2}\right) \\
C_{p} & \left.=\text { specific heat of collector fluid (Btu/gal }{ }^{\circ} \mathrm{F} \text { or } B t u / f t^{30} F\right) \\
p & =\text { collector pump/fan power factor } \\
q_{w} & =\text { water heater auxiliary energy input rate }(B t u / h) \\
t & =\text { time }(h)\end{aligned}$} \\
\hline
\end{tabular}


SEPI 
SECTION 3.0

RESULTS

Table 3-1 summarizes the physical characteristics of each monitored system. Appendix A contains detalled drawings of the systems and the sensor locations. All of the systems use a double-tank conflguration. Cold water enters the solar storage component, where it is preheated by the solar collectors before entering a second tank, which is equipped with electric or gas auxiliary heating. The overall performance of each system, summarized in Table 3-2, was derived mostly from the dally and monthly printouts of the real-time data reduction functions. The performance factors in Table 3-2 have the same definitions as the corresponding functions in Table 2-2. The following discussion of the performance of each system is based on these functions and examination of the detailed hourly data.

\subsection{SYSTEM 1: ALAMOSA SITE-BUILT WATER HEATING SYSTEM}

System 1 uses two ground-mounted, site-built collectors and a tank-in-jacket heat exchanger/storage component. The single-glazed collectors contain copper tubing wired to a flat-black absorber plate, in a parallel configuration. A propylene glycol solution is pumped through the heat exchanger, which consists of an uninsulated 66-gal (250-L) storage tank surrounded by a slightly larger jacket, with the heat transfer fluid circulating through the $1 / 2-i n .(1.3-\mathrm{cm})$ passage between the tank and jacket walls. The jacket is also uninsulated. Preheated water from this tank goes to a 52-gal (197-L) electric auxiliary water heater.

During this study the system performed we11, meeting $46 \%$ of the $64-g a 1 /$ day (242-L/day) hot water demand. The collector efficiency was $33 \%$, the highest of the seven systems monitored. The net solar efficiency was $23 \%$, with most of the thermal losses due to the uninsulated outer jacket. If this jacket were insulated to $R 11\left(0.5 \mathrm{~W} / \mathrm{m}^{2}{ }^{\circ} \mathrm{C}\right)$, the reduction in thermal 10 sses would raise the net solar efficiency to about $30 \%$ and the solar fraction from $46 \%$ to about $50 \%$.

Figure 3-1 shows the collector temperatures and weather conditions during a three-day span in September 1981. The collector flow rate of $3 \mathrm{gal} / \mathrm{min}$ $(0.2 \mathrm{~L} / \mathrm{s})$ gives a sufficient fluid capacitance rate $\left(1250 \mathrm{Btu} / \mathrm{h}{ }^{\circ} \mathrm{F}\right)\left(660 \mathrm{~V} /{ }^{\circ} \mathrm{C}\right)$ to maintain the temperature increase across the collector at $4^{\circ} \mathrm{F}\left(7^{\circ} \mathrm{C}\right)$ or less. This keeps the collector outlet temperature relatively low and results in a high collector heat removal factor and a high efficiency.

\subsection{SYSTEM 2: SAN LUIS SITE-BUILT WATER HRATING SYSTEM}

System 2 uses a roof-mounted site-built collector and an insulated 42-gal (159-L) storage tank. The collectors are double-glazed with fiberglass and use tube-on-plate construction in a parallel configuration. A copper heat exchanger coll is soldered to the storage tank exterior. The heat transfer fluid is a propylene glycol solution. 
Table 3-1. System Characteristics

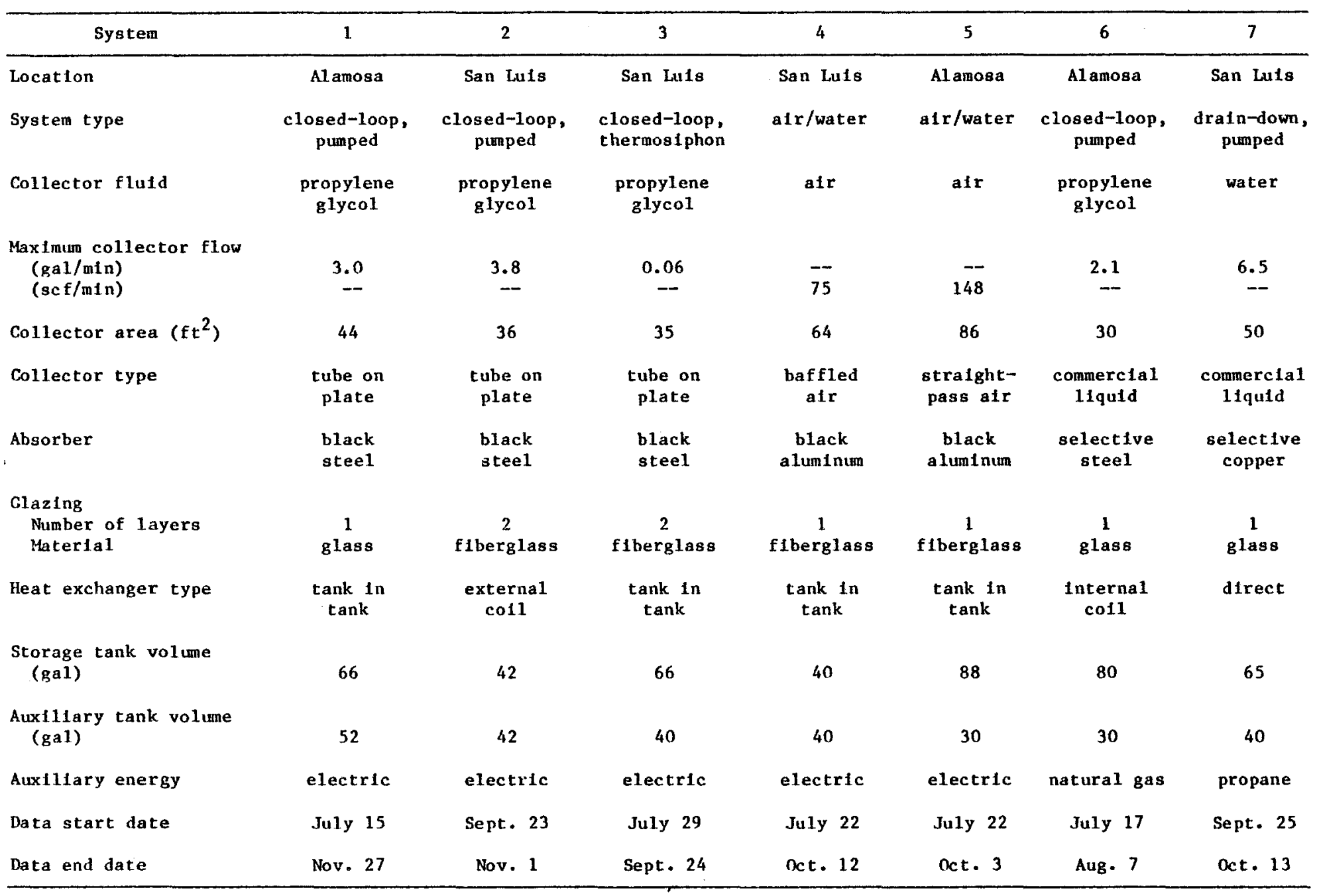

Note: $\mathrm{gal} / \mathrm{m1n} \times 0.06309=\mathrm{L} / \mathrm{s}$

$\mathrm{scf} / \mathrm{min} \times 3.468 \times 10^{-2}=\mathrm{kg} / \mathrm{h}$
$\mathrm{ft}^{2} \times 9.290304 \times 10^{-2}=\mathrm{m}^{2}$

gal $\times 3.785412=L$ 
Table 3-2. Performance Summary

\begin{tabular}{|c|c|c|c|c|c|c|c|}
\hline System & 1 & 2 & 3 & 4 & 5 & 6 & 7 \\
\hline Monitoring period (days) & 119 & 38 & 48 & 64 & 61 & 16 & 19 \\
\hline Gross solar energy collected $\left(10^{3} \mathrm{Btu} /\right.$ day $)$ & 28.3 & 15.3 & $6.1^{\mathrm{a}}$ & 24.3 & 32.5 & 16.7 & $26.9^{\mathrm{a}}$ \\
\hline Net solar heating $\left(10^{3} \mathrm{Btu} /\right.$ day $)$ & 19.4 & 14.4 & 4.8 & 11.0 & 11.7 & 15.9 & 25.9 \\
\hline Gross auxiliary energy use $\left(10^{3} \mathrm{Btu} /\right.$ day $)$ & 36.2 & 24.9 & 18.2 & 22.0 & 18.3 & 9.1 & 65.0 \\
\hline Net auxiliary heating $\left(10^{3} \mathrm{Btu} /\right.$ day $)$ & 23.0 & 11.1 & 5.5 & 13.8 & 10.6 & 6.9 & 38.5 \\
\hline Auxlliary efficiency & 0.64 & 0.44 & 0.30 & 0.63 & 0.58 & 0.76 & 0.60 \\
\hline Hot water use (gal/day) & 64 & 39 & 16 & 39 & 36 & 53 & 135 \\
\hline Average cold water temperature $\left({ }^{\circ} \mathrm{F}\right)$ & 61 & 63 & 63 & 63 & 61 & 88 & 63 \\
\hline Average preheat temperature $\left({ }^{\circ} F\right)$ & 98 & 108 & 99 & 97 & 101 & 124 & 86 \\
\hline Average hot water temperature $\left({ }^{\circ} \mathrm{F}\right)$ & 141 & 142 & 140 & 139 & 136 & 139 & 120 \\
\hline Average outdoor temperature $\left({ }^{\circ} \mathrm{F}\right)$ & 53 & 46 & 53 & 57 & 60 & 68 & 51 \\
\hline Incident radiation ( $3 t u / f t^{2}$ day) & 1920 & 1730 & 1910 & 1860 & 1700 & 2330 & 1930 \\
\hline Collector efficiency & 0.33 & 0.25 & $0.09^{a}$ & 0.20 & 0.22 & 0.24 & $0.28^{a}$ \\
\hline Net solar efficiency & 0.23 & 0.23 & 0.07 & 0.09 & 0.08 & 0.23 & 0.27 \\
\hline Solar fraction & 0.46 & 0.57 & 0.46 & 0.44 & 0.53 & 0.70 & 0.40 \\
\hline Purchased energy per gallon (Btu/gal) & 620 & 750 & 1130 & 670 & 780 & 240 & 520 \\
\hline Collector pump/fan energy $\left(10^{3} \mathrm{Btu} /\right.$ day $)$ & 3.8 & 4.2 & 0 & 4.0 & 9.7 & 3.6 & 5.2 \\
\hline Net coefficient of performance & 5.1 & 3.4 & - & 2.8 & 1.2 & 4.4 & 5.0 \\
\hline
\end{tabular}

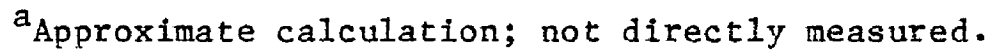

Note: $10^{3} \mathrm{Btu} /$ day $\times 1.0548=\mathrm{MJ} / \mathrm{day}$

gal/day $\times 3.785412=L /$ day

$\left({ }^{\circ} \mathrm{F}-32\right) / 1.8={ }^{\circ} \mathrm{C}$

$\mathrm{Btu} / \mathrm{ft}^{2}$ day $\times 11.348=\mathrm{kJ} / \mathrm{m}^{2}$ day

Btu/gal $\times 2.785297 \times 10^{-1}=\mathrm{kJ} / \mathrm{L}$ 


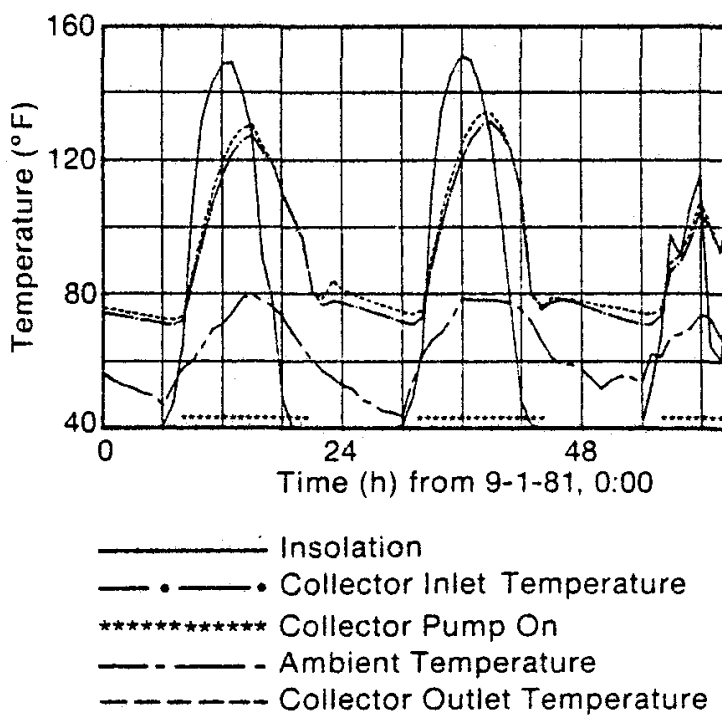

Conversion Factors: $\mathrm{Btu} / \mathrm{ft}^{2} \mathrm{~h} \times 3.152481=\mathrm{W} / \mathrm{m}^{2}$ $\left({ }^{\circ} \mathrm{F}-32\right) / 1.8={ }^{\circ} \mathrm{C}$

Figure 3-1. Operational Characteristics of the Alamosa Site-Built Water Heater (Site 1)

The system met $57 \%$ of a $39-\mathrm{gal} /$ day (159-L/day) hot water demand. As was true for three others of the seven systems tested, the hot water demand in this system was not sufficient to fully utilize the solar heater. The net solar heating was about equal to the standby heat loss from the electric water heater. Nevertheless, the net solar efficlency was $23 \%$, and the collector efficiency was $25 \%$. These figures would have been higher with a larger water load.

\subsection{SYSTEM 3: SAN LUIS SITE-BUILT THERMOSIPHON SYSTEM}

This system uses a ground-mounted, site-built collector, similar to the collector in system 2, but in a thermosiphon configuration. A propylene glycol solution circulates by thermal buoyancy between the collector and the storage tank/heat exchanger component located in an attic about $6 \mathrm{ft}(2 \mathrm{~m})$ above the top of the collector. Similar to system 1, the heat exchanger is a tank-in-jacket design, with the heat transfer fluid circulating between the tank and jacket walls. Due to space limitations in the attic, the tank is positioned horizontally. The outer jacket is insulated to $R I 1\left(0.5 \mathrm{~W} / \mathrm{m}^{2}{ }^{\circ} \mathrm{C}\right)$.

The system met $47 \%$ of a meager 16-gal/day ( $60-\mathrm{L} /$ day) hot water demand. Again, the small water demand reduced the solar heater performance, and the largest energy flow in the entire system was the standby heat loss from the electric auxiliary water heater. 
The net solar efficiency was $7 \%$, with a collector efficiency of about $9 \%$. The low collector efficlency was caused by low collector flow, which resulted in high collector temperatures and large thermal losses. Although the flow in the thermosiphon loop could not be directly measured, the calculated flow rate never exceeded $0.06 \mathrm{gal} / \mathrm{min}(4 \mathrm{~mL} / \mathrm{s})$, resulting in a collector heat removal factor of less than 0.2. The results can be seen in Fig. 3-2, where the temperature rise across the collector reaches $55^{\circ} \mathrm{F}\left(31^{\circ} \mathrm{C}\right)$.

The low flow and high temperatures are partly due to the high viscosity of the glycol solution (about six times that of water) and the relatively high collector inlet temperatures caused by the heat exchanger (compared to a direct system). The theoretical peak flow rate is about $0.6 \mathrm{gal} / \mathrm{min}$ $(40 \mathrm{~mL} / \mathrm{s}), 10$ times the calculated flow, and the maximum collector temperature rise is only about $20^{\circ} \mathrm{F}\left(11^{\circ} \mathrm{C}\right)$ [2].

The exact cause of the low thermosiphon flow is not clear. The collector is made with $1 / 2-i n .(1.3-\mathrm{cm})$-diameter pipe, soldered in a parallel configuration for low flow resistance, and the connecting pipe has a $1-i n$. (2.5-cm) diameter, sufficient to allow much higher flow rates. It is possible, however, that there is some major restriction in the piping or the heat exchanger/storage tank component.

\subsection{SYSTEM 4: SAN LUIS AIR-TO-WATER SYSTEM}

This system is an air-to-water system with a roof-mounted, site-built collector and an integral storage tank/heat exchanger component. The collector is a Ramstetter-type design with an aluminum absorber and a corrugated fiberglass glazing [3]. Metal baffles cause a serpentine air

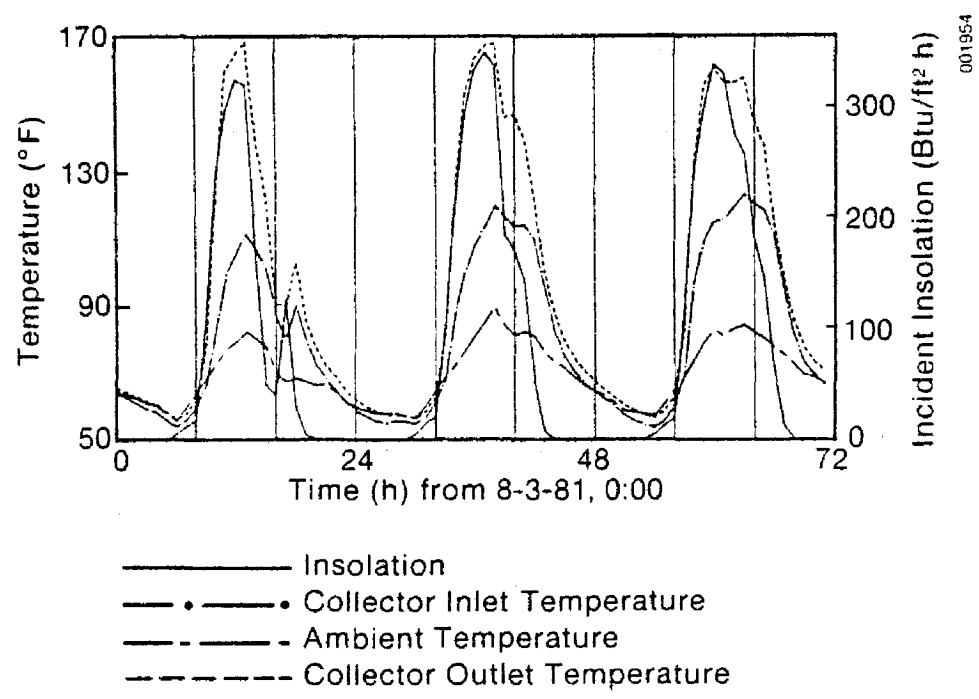

Conversion Factors: Btu/ $/ \mathrm{ft}^{2} \mathrm{~h} \times 3.152481=\mathrm{W} / \mathrm{m}^{2}$

$\left({ }^{\circ} \mathrm{F}-32\right) / 1.8={ }^{\circ} \mathrm{C}$

Figure 3-2. Operational Characteristics of the San Luis Thermosiphon Water Heater (Site 3) 
pattern through the collector. The 40-gal (151-L) storage tank is surrounded by an air passage through which the air is circulated from the collector.

The system met $46 \%$ of a $39-$ gal/day $(148-\mathrm{L} /$ day) hot water demand, with a net solar efficiency of $9 \%$ and a collector efficiency of $20 \%$. The collector efficiency measurement was relatively uncertain because a $25 \%$ collector air leakage rate made flow measurements difficult. Nevertheless, it is clear that much of the collected energy was not being used to heat the domestic water. Conduction losses through the outer tank wall could not account for all the lost energy.

Figure 3-3 shows a possible explanation for the energy loss. The collector inlet and outlet ducts are located inside the conditioned space of the house. One would therefore expect the collector inlet and outlet temperatures to approach room temperature (about $70^{\circ} \mathrm{F}$, or $21^{\circ} \mathrm{C}$ ) shortly after the collector fan shuts off in late afternoon. Instead, the collector outlet temperature remains well above room temperature, and the inlet temperature approaches the outdoor air temperature. This suggests a thermosiphon loss mechanism that operates whenever the collector fan is off. The warm storage tank is in direct contact with air in the collector loop. This air rises when heated by the tank, travels through the collector outlet duct to the collector, where it is cooled or mixed with outdoor alr (via collector leaks), and returns down the collector inlet duct to cool the storage tank. The air in the inlet duct is as much as $14^{\circ} \mathrm{F}\left(8^{\circ} \mathrm{C}\right)$ cooler than the air moving up the outlet duct.

Another similar thermal loss mechanism may be induced by leaks in the heat exchanger, so that indoor air leaks into the duct and is heated by the tank;

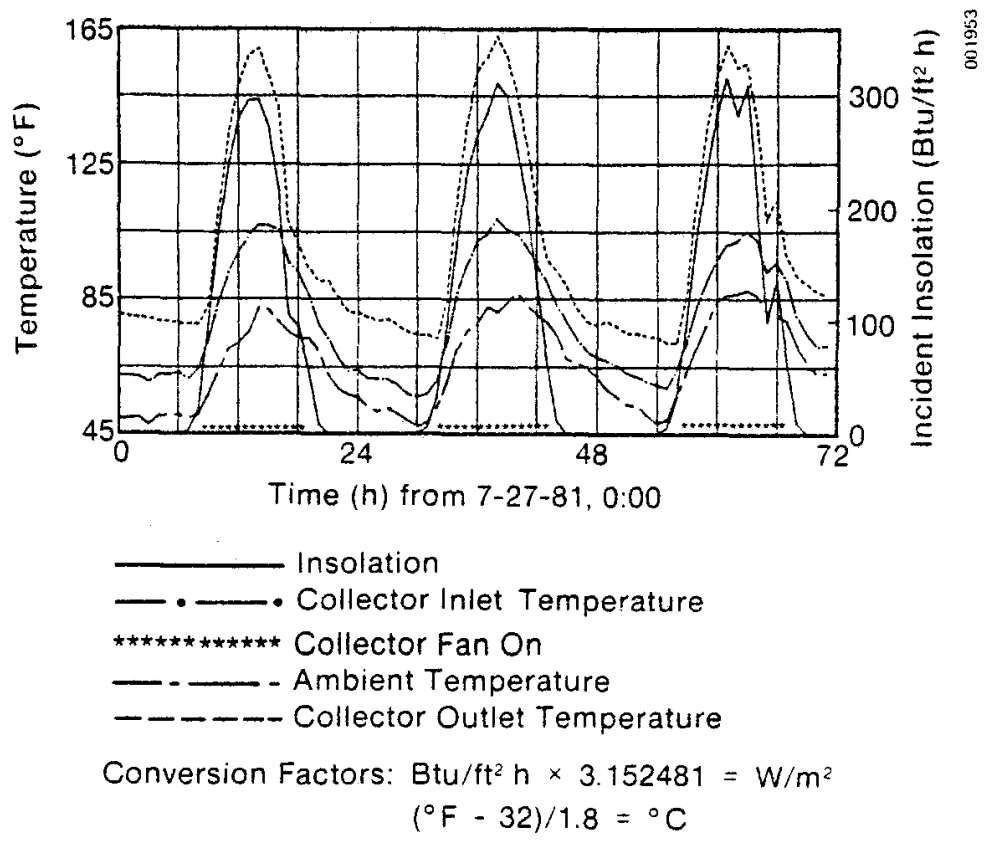

FHgure 3-3. Operational Characteristics of the San Luis Air-to-Water System (Site 4) 
this air then travels out through the collector. This chimney action can also remove energy from the storage tank.

Figure 3-3 also shows collector temperatures during fan operation. The large collector temperature difference (up to $40^{\circ} \mathrm{F}$, or $22^{\circ} \mathrm{C}$ ) is caused by the relatively small fluid capacitance rate, $80 \mathrm{Btu} / \mathrm{h}{ }^{\circ} \mathrm{F}\left(42 \mathrm{~W} /{ }^{\circ} \mathrm{C}\right)$ (compared to the pumped-1iquid systems). This results in a lower collector heat removal factor and higher collector outlet temperatures and thermal 10 sses.

\subsection{SYSTEM 5: AIAMOSA AIR-TO-WATER SYSTEM}

System 5 is an air-towater system. It uses a roof-mounted, site-built collector similar to the system-4 collector, except that the air path is straight rather than serpentine. The storage tank/heat exchanger component is located in the basement, with the collector inlet and outlet ducts in conditioned space.

The systern performed similarly to system 4 , heating $53 \%$ of a $36-g a 1 / d a y$ (136-L/day) load. Again, the solar performance was penalized by a sma11 hot water demand. The net solar efficiency was $8 \%$, and the collector efficiency was $22 \%$.

A thermosiphon loss mechanism occurs in this system as we11. As Fig. 3-4 shows, the temperature in the collector outlet duct remains above room temperature when the collector fan is off, while the inlet duct temperature approaches room temperature. It appears that basement air is leaking into the heat exchanger and traveling up to the collector (which has a $10 \%$ leakage rate), removing heat from the storage tank. There are backdraft dampers in the collector inlet duct just below the collector and in the outlet duct just above the tank. Apparently the damper near the tank leaks somewhat.

Other performance factors were similar to those of system 4, and Fig. 3-4 shows, again, as much as a $40^{\circ} \mathrm{F}\left(22^{\circ} \mathrm{C}\right)$ rise across the collector. One difference between the two systems is that this system consumes more electricity for the fan. The system coefficient of performance (COP) was 3.3 based on the collected energy and only 1.2 based on the net solar energy used. Since the fan motor is ventilated by the collector air flow, a significant amount of the collected heat is actually contributed by the fan. One reason for the low COP is that the collector fan continues to run in the afternoon until the collector temperature rise is close to zero. Because the specific heat of air is low, very little energy is collected and the cop during these hours is quite low.

\subsection{SYSTEM 6: ALAMOSA COMMERCIAL WATER HEATING SYSTEM}

System 6 uses two commercial collectors and a we11-insulated 80-gal (303-L) storage tank. The collectors are single-glazed, with a selective-surface steel absorber that is formed around the copper tubing. The heat transfer fluid is a propylene glycol solution. 


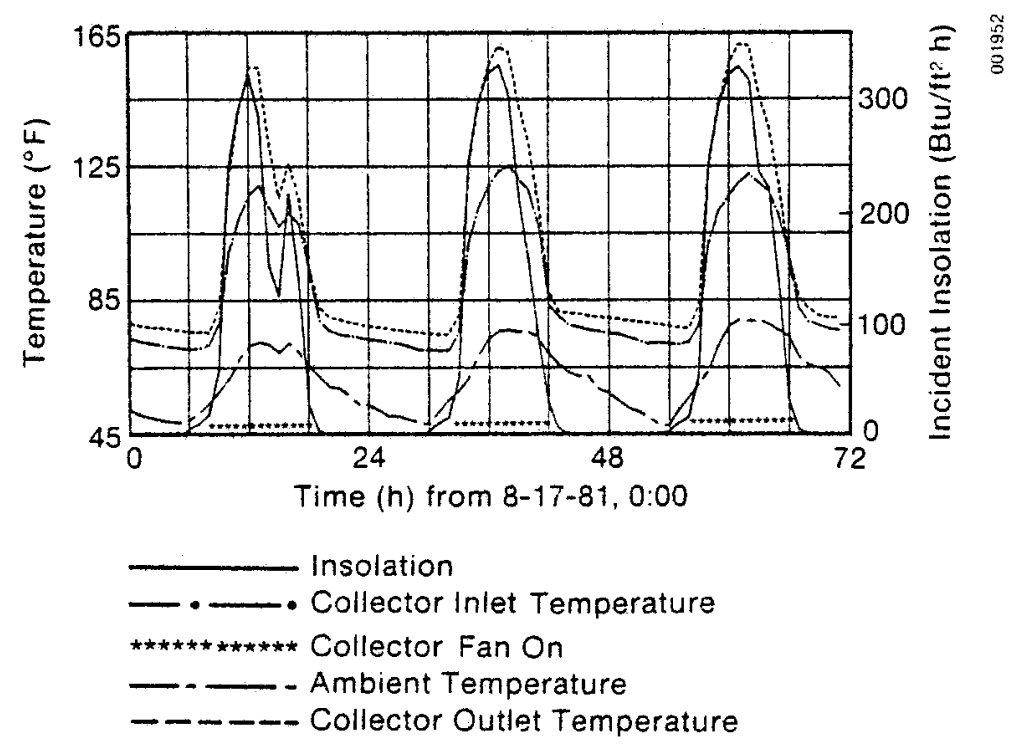

Conversion Factors: Btu/ft $\mathrm{h} \times 3.152481=\mathrm{W} / \mathrm{m}^{2}$

$$
\left({ }^{\circ} \mathrm{F}-32\right) / 1.8={ }^{\circ} \mathrm{C}
$$

\section{Figure 3-4. Operational Characteristics of the Alamosa Air-to-Water System (Site 5)}

The system met $70 \%$ of a $53-$ gal/day (200-I/day) hot water demand, preheating the water to an average of $124^{\circ} \mathrm{F}\left(51^{\circ} \mathrm{C}\right)$. The high temperature of the water supply--8 $8^{\circ} \mathrm{F}\left(31^{\circ} \mathrm{C}\right)$--resulted from nearby geothermal activity. The collector efficiency was $24 \%$, and the net solar efficiency was $23 \%$.

Data collection at this site stopped when the data acquisition hardware was seriously damaged during a severe lightning storm. All the sites were soon equipped with lightning arresters that direct any lightning charge to ground without damaging equipment. No further lightning damage resulted, despite the high incidence of lightning in the San Luis Valley.

\subsection{SYSTEM 7: SAN LUIS COMMERCIAL WATER HEATING SYSTEM}

System 7 uses a commercial collector and a 65-gal (246-L) storage tank in a drain-down configuration. The collector is single-glazed with a selectivesurface copper absorber.

The system contributed $40 \%$ of a 135-gal/day (511-L/day) hot water load. The net solar efficiency was $27 \%$ and the collector efficiency was about $28 \%$. The high collector efficiency was partly due to the large hot water demand (the family includes five young children). The average preheat temperature was only $86^{\circ} \mathrm{F}\left(30^{\circ} \mathrm{C}\right)$, which kept the collector temperature low and improved the efficiency. The average hot water output temperature was relatively low at 
$120^{\circ} \mathrm{F}\left(49^{\circ} \mathrm{C}\right)$, partly because the 40 -gal $(151-\mathrm{L})$ gas-fired water heater could not always keep up with the water use. Had the output temperature been $140^{\circ} \mathrm{F}$ $\left(60^{\circ} \mathrm{C}\right)$, as in the other systems, the solar fraction would have been on $1 \mathrm{y} 30 \%$.

This system performed remarkably well despite a serious control flaw. Due to an improperly placed sensor or a faulty controller, the collector pump cycled on and off an average of 49 times per day, draining the collector each time. Although most of the cycling occurred during times of marginal solat input, it wasted a significant fraction of the collected energy and made measurement of the collected energy impossible. If this problem is corrected in the future, the system performance should be excellent. 


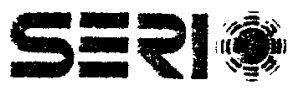




\section{SECTION 4.0}

\section{CONCLUSIONS}

\subsection{SYSTEM PERPORMANCE}

The system efficiencles listed in Table 3-2 indicate that the best overall performance was by the pumped-1iquid systems. Systems $1,2,6$, and 7 all had system efficiencies greater than $20 \%$, with solar fractions between $40 \%$ and $70 \%$. The lower efficiency of the closed-loop thermosiphon system 3 was due to low collector flows and a very small hot water demand.

The alr-to-water systems 4 and 5 did not perform as well as the pumped-liquid systems. The low specific heat of air caused lower collector heat removal factors; the collectors and heat exchangers leaked significantly; and thermosiphon and chimney air circulation mechanisms caused substantial heat losses when the collector fan was off.

\subsection{COLLECTOR PERPORMANCE}

The collector efficiencies in Table 3-2 suggest that the site-built liquid collectors (in systems 1 and 2) performed as well as the commercial collectors (in systems 6 and 7 ). The systems containing the commercial collectors, however, had some perfornance penalties: the high water supply temperature in system 6 and the control problem in system 7. It would be unrealistic to conclude that site-built collectors are as efficient as commercial models in general; however, these results show that the site-built collectors do perform adequately.

The air collectors operated with acceptable, albeit uncertain, efficiency. The air leakage rates, $25 \%$ in system 4 and $10 \%$ in system 5 , decreased co 1 lector performance and promoted thermosiphon heat loss mechanisms that decreased system efficiency.

\subsection{LOAD EFFECTS}

The performance of each system depended somewhat on the hot water demand it supplied. A large hot water load resulted in the use of more solar energy and reduced the storage and collector temperatures, increasing system efficiency. At the sites with small loads, the largest energy flows in the water heating system were standby tank heat losses. In these cases, additional tank insulation would probably provide more energy savings at less cost that even the least expensive site-built solar heater. At the sites with larger loads, low-cost energy and water conservation measures would augment the value of the solar heater by reducing the amount of purchased energy and would improve the cost-effectiveness of the entire system. Water conservation, however, will make the solar heater appear less efficient for the reason noted above. 


\subsection{FUTURE WORK}

The disappointing performance of the thermosiphon system suggests the necessity for future work in this area. Freeze-proof thermosiphon systems have not been exhaustively researched, and further testing of low-cost designs would be useful. This testing should include extensive instrumentation of the storage component to isolate the various energy flows more precisely than was possible in this project. 
SECTION 5.0

REFERENCES

1. Frey, D.; Swlsher, J.; Holtz, M. 1982. "Class B Performance Monitoring of Passive/Hybrid Solar Buildings." Proceedings of the ASME Solar Energy Conference; Albuquerque, NM; Apr. 1982. Golden, CO: SERI/TP-254-1492. Solar Energy Research Institute.

2. Mertol, D.; Place, W.; Webster, T. 1981. "Detailed Loop Model Analysis of Liquid Solar Thermosiphons with Heat Exchangers." Solar Energy. Vo1. 27 (No. 5): pp. 367-86.

3. Kornher, S.; et al. 1981. "Solar Air Collectors." Alamosa, Co: San Luis Valley Solar Energy Association.

4. Kline, S.; McClintock, F. 1953. "Describing Uncertainties in Single Sample Experiments." Mechanical Engineering. 
S=P| 
APPENDIX A

DETAILED SYSTEM DRAWINGS 


\section{SEPI}


(1) COLD WATER SUPPLY LINE

(2) HOT WATER OUTLET LINE

(3) $i=$ CHECK VALVE

(4) $T=$ GATE VALVE

(5) COLD flOW RATE METER

(6) TEMPERATURE SENSOR

(7) ELECTRIC WATER HEATER

(B) solar collector panel.

(9) Air release valve

-(12) (10) CIRCULATING PUMP

(ii) COLLECTOR FLUID FLOW METEF

(14) (12) PREHEAT TANK $66 \mathrm{GAL}$.

(B) EXPANSION TANK

(14) HEAT EXCHANGER JA.CKET TI - COLD WATER SUPPLI TEMP

TZ-PRE-HEAT OUTLE: TEMP.

T3-BACK UP OUTLET TEMP. TCI-COLLECTOR INLET TEMP. TCO-COLLECTOR XLILET TEMP.

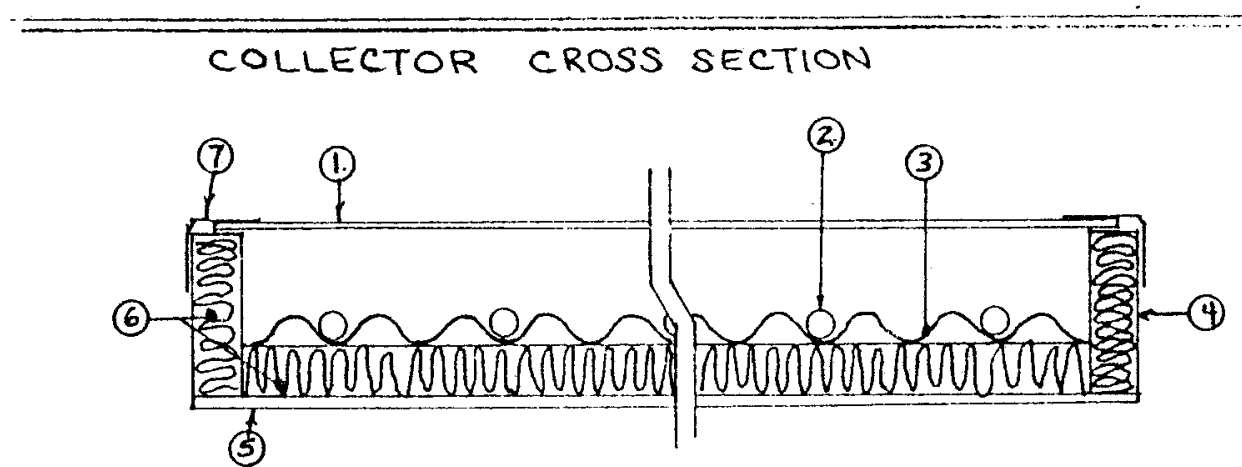

(1) 3/16" TEMPERED GLASS

(2) I/Z"COPPER RISER (3/4" HEADER)

(3) CORRLGATED IRON ABSORBER PLATE

(4) COLLECTOR SIDE-26, SHEET METAL

(5) 1/8"MASONITE BACKING

(6) I" J.M. "DLLTBOARD INSLLATKON

(7) GLASS RETAINER 26y SHEET METAL

(5) 


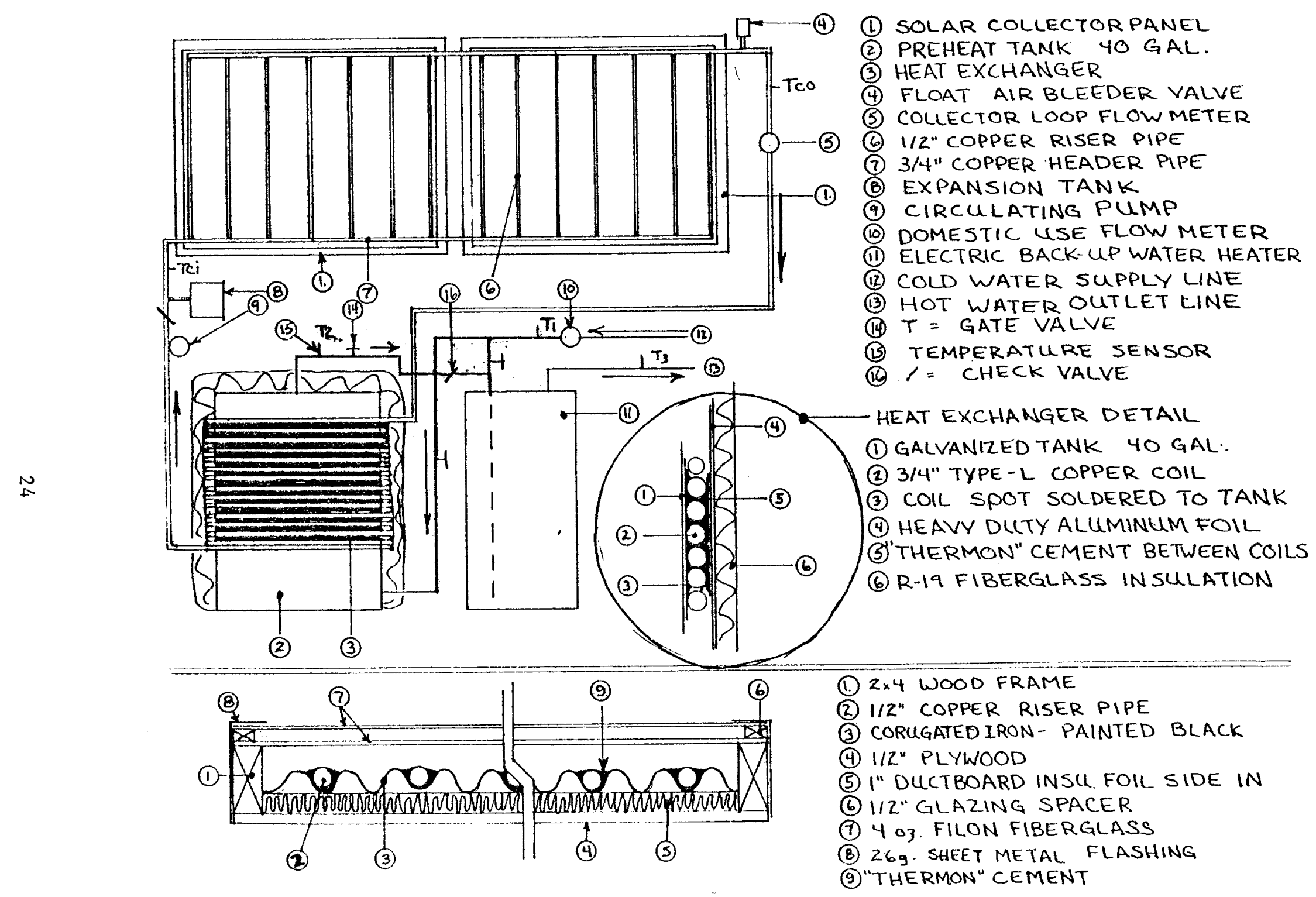




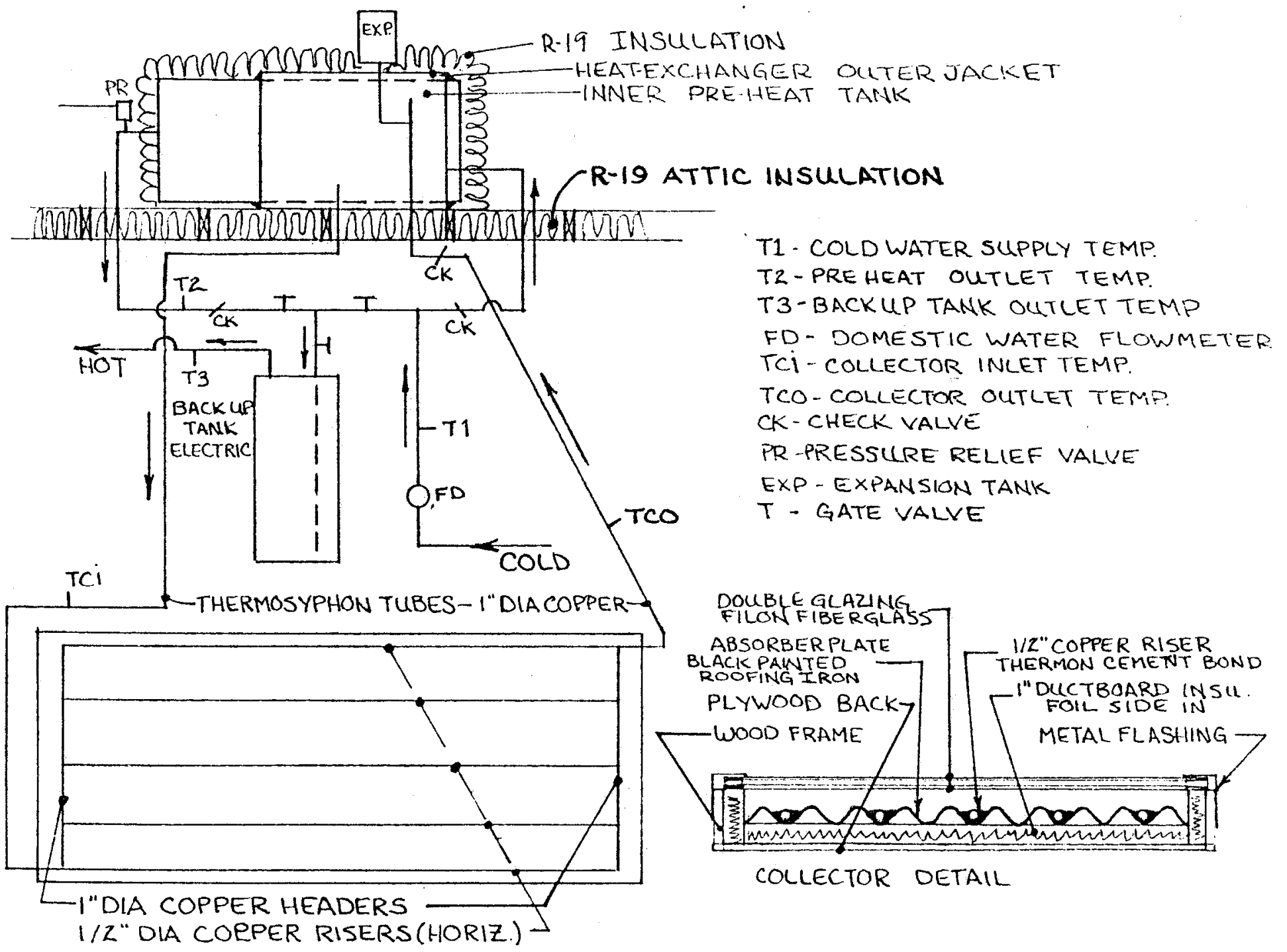

San Luis Valley Site 3: System Schematic 


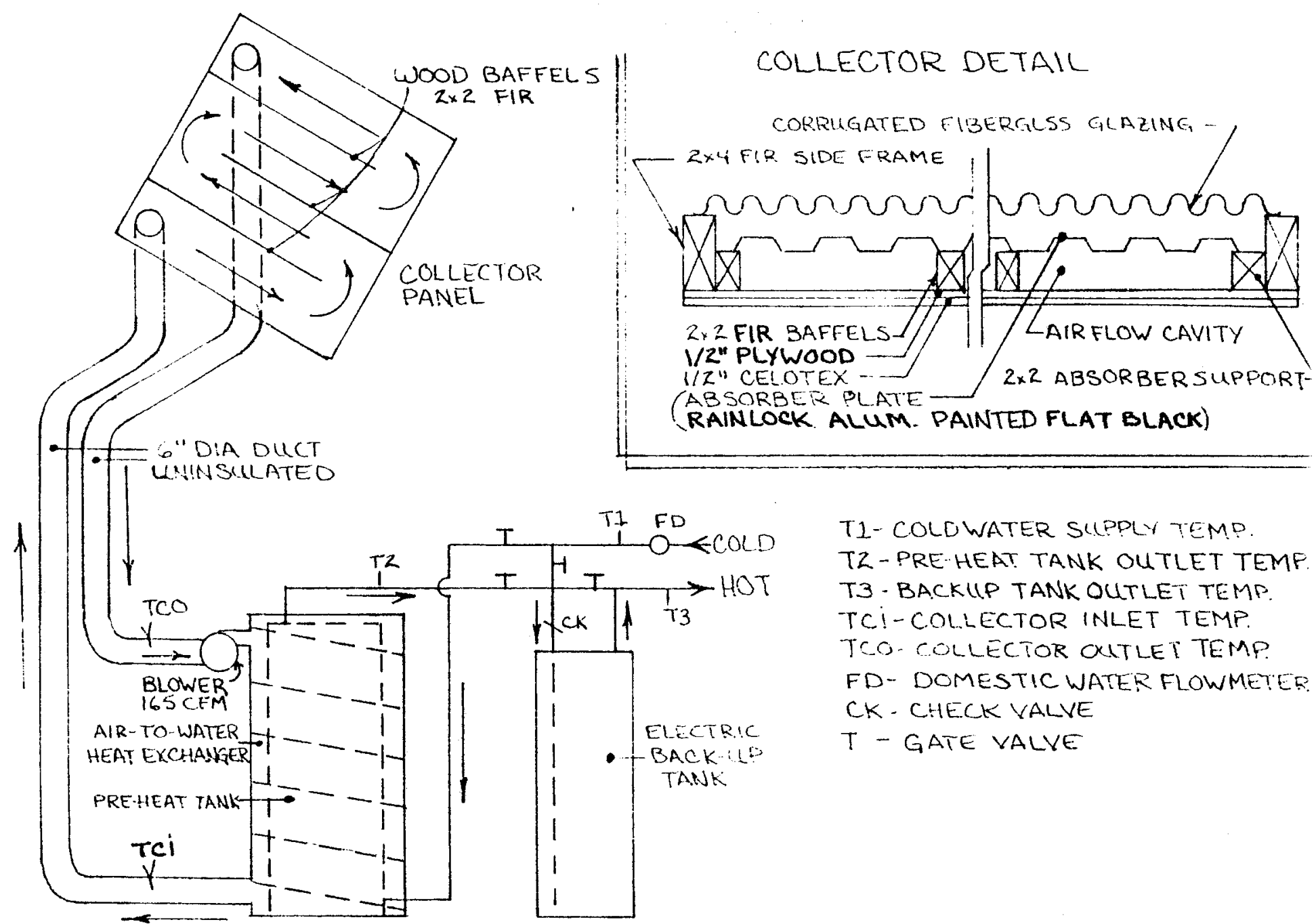


T1 - COLD WATER SUPPLY TEMP.

TZ-PRE-HEAT OUTLET TEMP.

T3 - BACKUP TANK OUTLET TEMP.

FD-DOMESTIC WATER FLOWMETER

TCI-COLLECTOR INLET AIR TEMP.

TCO-COLLECTOR OUTLET AIR TEMP.

DT - $9: 3^{\circ}$ DIFFERENTIAL THERMOSTAT

CK - CHECK VALVE
$T$ - GATE VALVE

COLLECTOR DETAIL
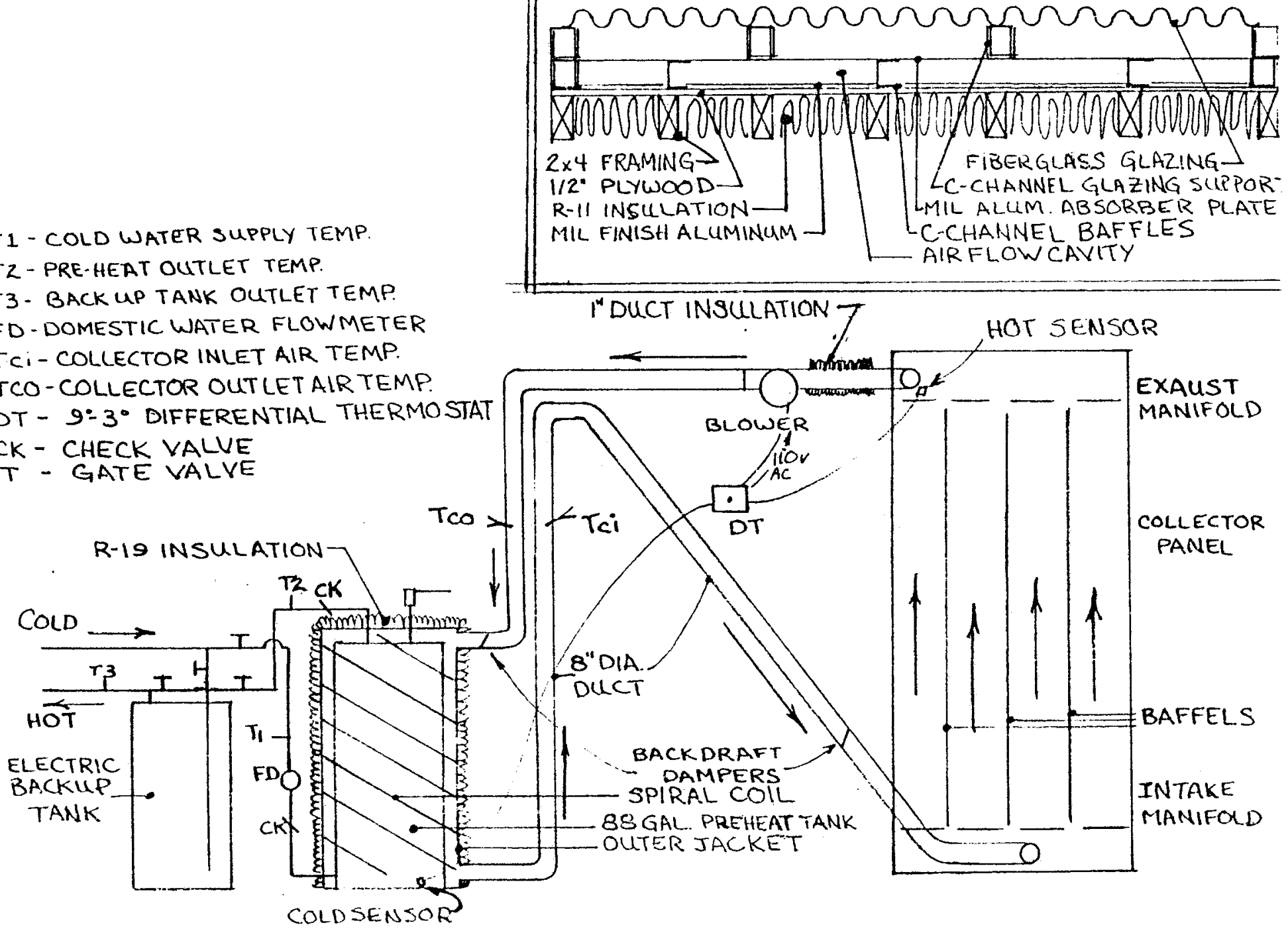

San Luis Valley Site 5: System Schematic 
T1 - COLD WATER SUPPLY TEMP.

T2 - PRE HEAT TANK OUTLET TEMP.

T3 - BACK-UP TANK OUTLET TEMP.

FD-DOMESTIC WATER FLOWMETER

FC-COLLECTOR FLUID FLOWMETER

TCI-COLLECTOR INLET TEMP.

TCO-COLLECTOR OUTLET TEMP.

CK-CHECK VALVE

PR-PRESSULE RELIEF

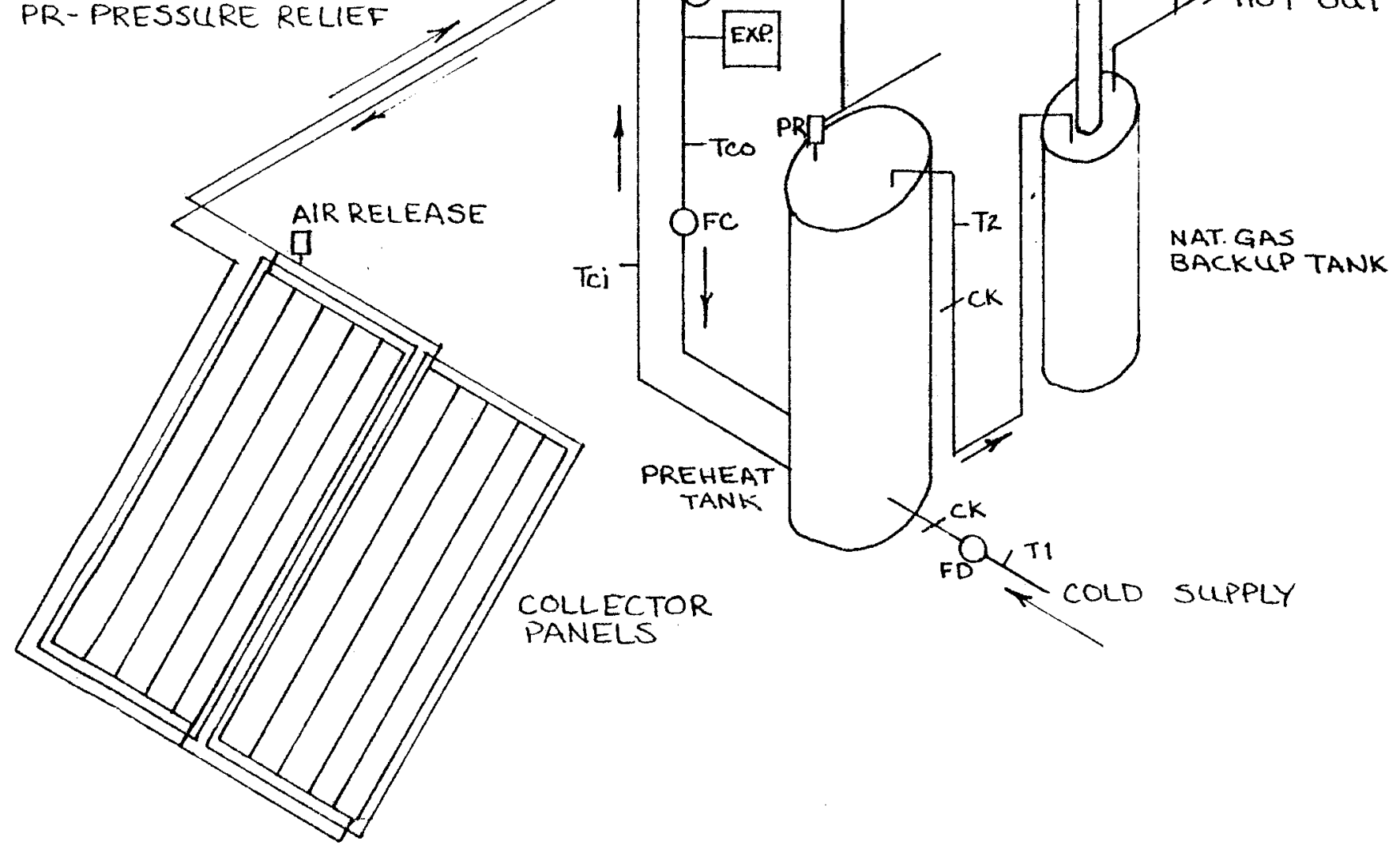


T1 - COLD WATERSUPPLY TEMP

T2-PREHEAT OUTLET TEMP

T3- BACK UP TANK OUTLET TEMP

TCI-COLLECTOR FLLLID INLET TEM: TCO-COLLECTOR FLUID OUTLET TEM: FD-DOMESTK WATER FLOWMETE

FC - COLLECTOR FLOWMETER

CK- CHECK VALVE

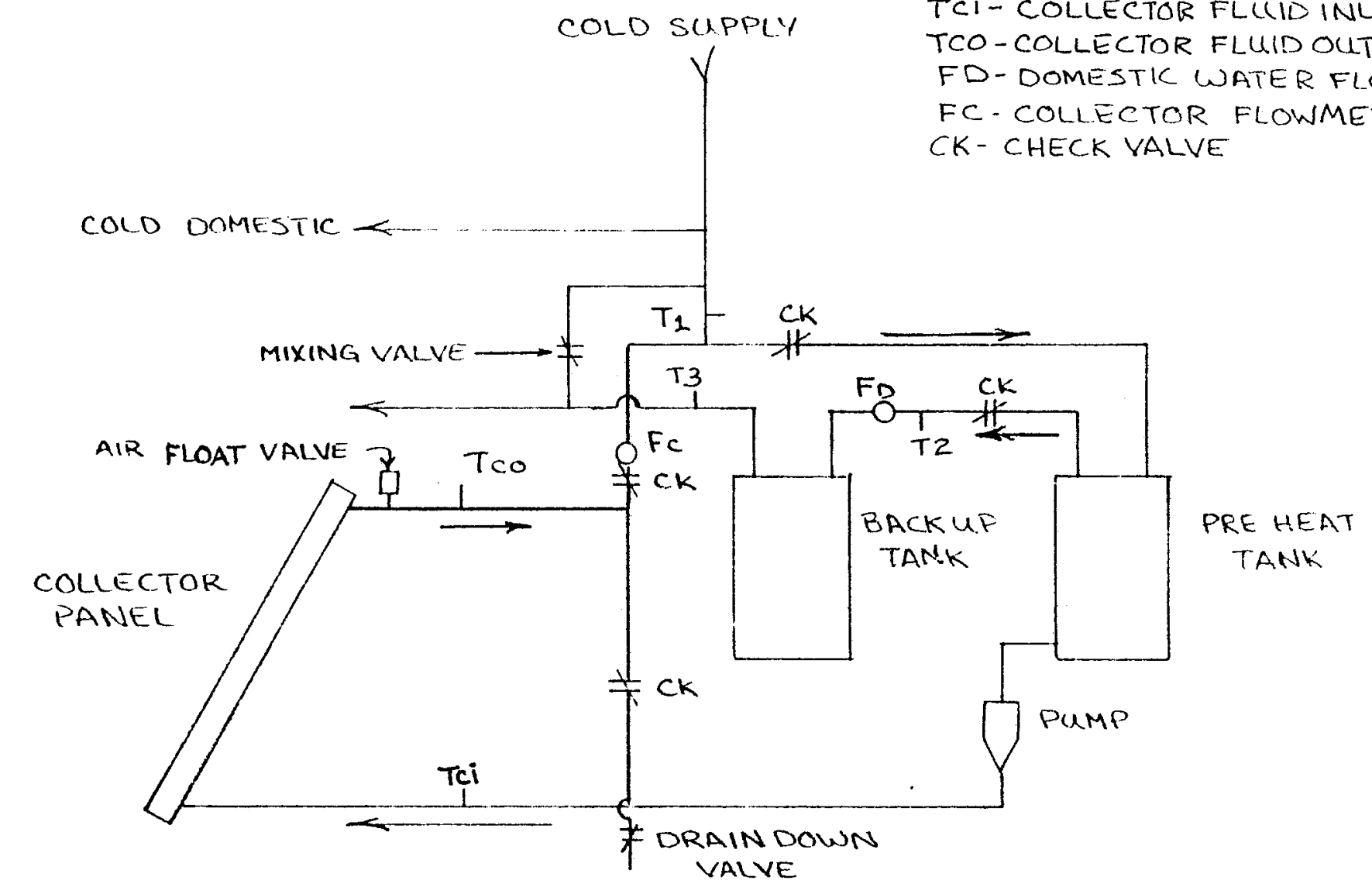

San Luis Valley Site 7: System Schematic 
SEPI 


\section{APPENDIX B}

\section{UNCERTAINTY ANALYSIS}

The following calculations relate the estimated experimental errors of the individual measurements to the uncertainty of the energy quantities derived from these measurements. The uncertainty calculations are based on representative instantaneous values of each measurement. They provide a guide to the magnitude of the uncertainties and their sensitivity to individual measurement exrors.

The derived energy quantities are integrated values based on transient measurements made at 15-second intervals over the span of several months. A complete time-dependent uncertainty analysis would be an enormous task, far beyond the scope of this project.

The analysis shows that the calculations of the gross auxiliary energy use, the net auxiliary heating, and the net solar heating were relatively precise, with calculated uncertainties of $4 \%$ to $6 \%$. The values for the gross solar energy collected, for both air and liquid systems, had a large uncertainty: $28 \%$ to $36 \%$.

Basic Equation for Uncertainty of Derived Quantities*

$$
\Delta R=\left[\sum\left(\frac{\partial R}{\partial V_{i}} \Delta v_{i}\right)^{2}\right]^{1 / 2}
$$

where

\footnotetext{
$\Delta \mathrm{R}=$ result uncertainty

$\Delta v_{i}=$ measured value uncertainty

$\partial R / \partial V_{i}=$ partial differential of the derived result with respect to an individual measurement
}

The calculated uncertainties are expressed as percentages of the derived results for the major system energy flows. See Tables 2-1 and 2-2 for definitions of the symbols used in the following equations.

Gross Solar Energy Collected by Glycol Systems

$$
\begin{aligned}
\frac{\Delta Q_{g s}}{Q_{g s}} & =\left[\left(\frac{\Delta C_{p}}{C_{p}}\right)^{2}+\left(\frac{\Delta F_{c}}{F_{c}}\right)^{2}+2\left(\frac{\Delta T}{T_{c o}-T_{c i}}\right)^{2}\right]^{1 / 2} \\
& =\left[0.02^{2}+0.02^{2}+2(0.2)^{2}\right]^{1 / 2}=0.284 \text {, or } 28.4 \%
\end{aligned}
$$

Notes: The specific heat has $2 \%$ error due to temperature dependence and uncertainty of the glycol content. The high-temperature Kent flowneter is accurate to $2 \%$ for values between 0.22 and $22 \mathrm{gal} / \mathrm{min}(0.014$ to $1.4 \mathrm{~L} / \mathrm{s})$. The temperature transducers are accurate to $1^{\circ} \mathrm{F}\left(0.6^{\circ} \mathrm{C}\right)$, and a representative temperature difference is $5^{\circ} \mathrm{F}\left(3^{\circ} \mathrm{C}\right)$.

*See Ref. 4. 
Gross Solar Energy Collected by Air Systems

$$
\begin{aligned}
\frac{\Delta Q_{g s}}{Q_{g s}} & =\left[\left(\frac{\Delta C_{p}}{C_{p}}\right)^{2}+2\left(\frac{\Delta F_{c}}{F_{c}}\right)^{2}+4\left(\frac{\Delta T}{T_{c o}-T_{c i}}\right)^{2}\right]^{1 / 2} \\
& =\left[0.01^{2}+2(0.25)^{2}+4(0.033)^{2}\right]^{1 / 2} \\
& =0.360, \text { or } 36.0 \%
\end{aligned}
$$

Notes: The specific heat has $1 \%$ error. The flow rate error is $25 \%$, due to leakage and the assumption of constant flow. The temperature transducers are accurate to $1^{\circ} \mathrm{F}\left(0.6^{\circ} \mathrm{C}\right)$, and a representative temperature difference is $30^{\circ} \mathrm{F}$ $\left(17^{\circ} \mathrm{C}\right)$.

Net Solar Heating or Net Auxiliary Heating

$$
\begin{aligned}
\frac{\Delta Q_{\mathrm{ns}}}{Q_{\mathrm{ns}}} & =\frac{\Delta \mathrm{Q}_{\mathrm{na}}}{\mathrm{Q}_{\mathrm{na}}}=\left[\left(\frac{\Delta \mathrm{C}_{\mathrm{p}}}{\mathrm{C}_{\mathrm{p}}}\right)^{2}+\left(\frac{\Delta \mathrm{F}_{\mathrm{d}}}{\mathrm{F}_{\mathrm{d}}}\right)^{2}+2\left(\frac{\Delta \mathrm{T}}{\mathrm{T}_{2}-\mathrm{T}_{1}}\right)^{2}\right]^{1 / 2} \\
& =\left[0.01^{2}+0.015^{2}+2(0.025)^{2}\right]^{1 / 2} \\
& =0.040, \text { or } 4.0 \%
\end{aligned}
$$

Notes: The specific heat has $1 \%$ error. The kent low-temperature flowmeter is accurate to $1.5 \%$ for values between 0.25 and $25 \mathrm{gal} / \mathrm{min}(0.016$ to $1.6 \mathrm{~L} / \mathrm{s})$. The temperature transducers are accurate to $1^{\circ} \mathrm{F}\left(0.6^{\circ} \mathrm{C}\right)$, and a representative temperature difference across the preheat tank or the auxiliary tank is $40^{\circ} \mathrm{F}$ $\left(22^{\circ} \mathrm{C}\right)$.

Gross Auxiliary Energy Use (Electricity)

$$
\begin{aligned}
\frac{\Delta Q_{\mathrm{ga}}}{\mathrm{Q}_{\mathrm{ga}}} & =\left[\left(\frac{\Delta \mathrm{EC}_{\mathrm{w}}}{E C_{\mathrm{w}}}\right)^{2}+\left(\frac{\Delta \mathrm{V}}{\mathrm{V}}\right)^{2}\right]^{1 / 2} \\
& =\left[0.06^{2}+0.01^{2}\right]^{1 / 2} \\
& =0.061, \text { or } 6.1 \%
\end{aligned}
$$

Notes: The AMPROBE current transducer is accurate to $1 \mathrm{~A}$, and a representative current is $16.7 \mathrm{~A}(4 \mathrm{~kW}$ at $240 \mathrm{~V})$. The AC voltage has $1 \%$ error. 
Gross Auxillary Energy Use (Natural Gas or LPG)

$$
\begin{aligned}
\frac{\Delta Q_{g a}}{Q_{g a}} & =\left[\left(\frac{\Delta q_{w}}{q_{w}}\right)^{2}+\left(\frac{\Delta t_{w}}{t_{w}}\right)^{2}\right]^{1 / 2} \\
& =\left[0.03^{2}+0.05^{2}\right]^{1 / 2} \\
& =0.058, \text { or } 5.8 \%
\end{aligned}
$$

Notes: The energy input rate is accurate to only $3 \%$ due to the errors in the gas flow measurement and in the estimate of the heating value of the fuel. The burner on-time error is one data scan interval (15 seconds), and a representative on-time is 5 minutes. 
SEP। 


\section{APPENDIX C}

HORIZONTAL INSOLATION MEASUREMENTS (Btu/ft ${ }^{2}$ day)*

$\frac{\text { Month }}{\text { July }(15 \text { to } 31)}$

August

September

october

November ( 1 to 26 )

$\begin{array}{cc}\text { Alamosa } & \text { San Luis } \\ 2130 & -- \\ 2040 & 1900 \\ 1720 & 1810 \\ 1390 & 1410 \\ 1150 & --\end{array}$

$*_{\mathrm{Btw}} / \mathrm{ft}^{2}$ day $\times 11.348=\mathrm{kJ} / \mathrm{m}^{2}$ day. 


\begin{tabular}{|c|c|c|c|}
\hline $\begin{array}{l}\text { Document Control } \\
\text { Page }\end{array}$ & $\begin{array}{l}\text { 1. SEAI Report No. } \\
\text { SERI/TR-254-1727 }\end{array}$ & 2. NTIS Accession No. & 3. Recipient's Accession No. \\
\hline \multirow{2}{*}{\multicolumn{3}{|c|}{$\begin{array}{l}\text { 4. Title and Subtitle } \\
\text { Measured Performance Results: Low-Cost Solar Water } \\
\text { Heating Systems in the San Luis Valley }\end{array}$}} & $\begin{array}{l}\text { 5. Publication Date } \\
\text { January } 1983\end{array}$ \\
\hline & & & 6. \\
\hline \multicolumn{3}{|l|}{$\begin{array}{l}\text { 7. Author(s) } \\
\text { Joel Swisher }\end{array}$} & 8. Performing Organization Rept. No. \\
\hline \multirow{2}{*}{\multicolumn{3}{|c|}{$\begin{array}{l}\text { 9. Performing Organization Name and Address } \\
\text { Solar Energy Research Institute } \\
1617 \text { Cole Boulevard } \\
\text { Golden, Colorado } 80401\end{array}$}} & $\begin{array}{c}\text { 10. Project/Task/Work Unit No. } \\
1119.70\end{array}$ \\
\hline & & & $\begin{array}{l}\text { 11. Contract (C) or Grant (G) No. } \\
\text { (C) } \\
\text { (G) }\end{array}$ \\
\hline \multirow{2}{*}{\multicolumn{3}{|c|}{ 12. Sponsoring Organization Name and Address }} & $\begin{array}{l}\text { 13. Type of Report \& Period Covered } \\
\text { Technical Report }\end{array}$ \\
\hline & & & 14. \\
\hline \multicolumn{4}{|l|}{ 15. Supplementary Notes } \\
\hline \multicolumn{4}{|c|}{$\begin{array}{l}\text { 16. Abstract (Limit: } 200 \text { words) } \\
\text { This report summarizes the measured performance of seven low-cost solar water } \\
\text { heating systems in the San Luis Valley of southern colorado. During the summer } \\
\text { and fall of } 1981 \text {. SERI monitored a variety of low-cost solar water heating } \\
\text { system designs and components. Five systems had site-built collectors, and } \\
\text { four included low-cost tank-in-jacket heat exchanger/storage tank components. } \\
\text { Two were air-to-water systems. The five liquid-based systems included a drain- } \\
\text { down design, a propylene glycol-charged thermosiphon system, and three pumped- } \\
\text { glycol systems. The pumped-1iquid systems performed the best, with system } \\
\text { efficiencies greater than } 20 \% \text { and solar fractions between } 40 \% \text { and } 70 \% \text { The air- } \\
\text { to-water systems did not perform as well because of leakage in the collectors and } \\
\text { heat exchangers. The thermosiphon system performed at lower efficiency because } \\
\text { the collector flows were low. }\end{array}$} \\
\hline \multirow{2}{*}{\multicolumn{4}{|c|}{$\begin{array}{l}\text { 17. Document Anaiysis } \\
\text { a. Descriptors Colorado; Comparative evaluations; Data acquisition systems; Solar } \\
\text { Water heaters }\end{array}$}} \\
\hline & & & \\
\hline \multirow{2}{*}{\multicolumn{3}{|c|}{$\begin{array}{l}\text { 18. Availabiity Statement } \\
\text { National Technical Information Service } \\
\text { U.S. Department of Commerce } \\
5285 \text { Port Royal Road } \\
\text { Springfield, Virginia } 22167\end{array}$}} & $\begin{array}{l}\text { 19. No. of Pages } \\
44\end{array}$ \\
\hline & & & $\begin{array}{l}\text { 20. Price } \\
\$ 4.50\end{array}$ \\
\hline
\end{tabular}

